\title{
Study on aerosol properties over Madrid (Spain) by multiple instrumentation during SPALI10 lidar campaign
}

\section{Estudio de las propiedades de los aerosoles sobre Madrid (España) mediante multiples instrumentos durante la campaña lidar SPALI10}

\author{
F. Molero(1), M. Sicard(2), F. Navas-Guzmán(3), J. Preißler(4), A. Amodeo(5), \\ V. Freudenthaler(6), A. J. Fernandez(1), S. Tomas ${ }^{(2)}$, M. J. Granados(3), F. Wagner ${ }^{(4)}$, \\ A. Giunta(5), I. Mattis(7), M. Pujadas(1), A. Comeron(2), L. Alados-Arboledas( ${ }^{(3)}$, \\ J. L. Guerrero-Rascado(3,4), G. D’Amico(5), D. Lange(2), J. A. Bravo(3), D. Kumar(2), \\ G. Pappalardo(5), J. Giner(2), C. Muñoz(2), F. Rocadenbosch(2) \\ 1. Centro de Invest. Energ., Medioamb. y Tecn. (CIEMAT), Avda Complutense, 22. Madrid, 28040. Spain. \\ 2. Department of Signal Theory and Comunications, Remote Sensing Lab., Universitat Politécnica de \\ Catalunya/Institut d'Estudis Espacials de Catalunya, Barcelona, Spain.
}

3. Andalusian Center for Environmental Research (CEAMA), University of Granada - Autonomous Goverment of Andalusia, Av. del Mediterráneo s/n, 18071, Granada, Spain.

4. Évora Geophysics Centre (CGE), University of Évora, Rua Romão Ramalho 59, 7000, Évora, Portugal.

5. Istituto di Metodologie per l'Analisi Amb. CNR-IMAA, C.da S. Loja, Tito Scalo, Potenza, I-85050, Italy.

6. Ludwig-Maximilians Universität, Meteorological Institute, Theresienstr. 37, 80333 München, Germany. 7. Leibniz Institute for Tropospheric Research, Leipzig, Germany.

(*) Email: f.molero@ciemat.es

Recibido / Received: 13/07/2012. Revisado / Revised: 06/11/2012. Aceptado / Accepted: 19/11/2012.

DOI: http://dx.doi.org/10.7149/0PA.45.4.405

\begin{abstract}
:
Four co-located multiwavelength Raman lidar systems (Madrid, Granada, Barcelona and Evora) measured simultaneously to a reference system (Potenza) in order to assess their performances during the intercomparison campaign: SPALI10, (SPAin Lidar Intercomparison 2010) that took place in Madrid from 18 October to 5 November 2010. Multiwavelength Raman lidar systems provide relevant vertically-resolved characteristics of aerosol optical properties. The products provided by the lidar systems were compared with ancillary data. At ground level, aerosol size distributions were continuously monitored. Additionally, the column integrated characterization of the atmospheric aerosol was performed by means of a sun photometer. The extensive dataset obtained during SPALI10 field campaign enables to compare ground-level in situ measurements with remote sensing techniques to determine vertically-resolved optical and microphysical properties of aerosols. Several relevant features shown in the comparison of the results obtained by the different instruments are discussed in this work.
\end{abstract}

Key words: Aerosols, Lidar, Size Distributions.

\section{RESUMEN:}

Cuatro sistemas lidar Raman multifrecuencia (Madrid, Granada, Barcelona y Evora), tomaron medidas simultáneamente a un sistema de referencia (Potenza) para verificar su funcionamiento durante la campaña de intercomparación: SPALI10, (SPAin Lidar Intercomparison 2010) que tuvo lugar en Madrid entre el 18 de Octubre y el 5 de Noviembre de 2010. Estos sistemas lidar Raman multifrecuencia proporcionan propiedades ópticas de los aerosoles con resolución vertical. Los perfiles suministrados por los sistemas lidar se compararon con información complementaria proporcionada por otra instrumentación, tal como la distribución de tamaños de los aerosoles medida de manera continua a nivel de superficie o la caracterización de la columna de aerosoles 
obtenida por fotómetros solares. El amplio conjunto de medidas obtenido durante la campaña SPALI10 permite evaluar algunos aspectos de las propiedades ópticas y microfísicas de los aerosoles resueltos en altura. En este trabajo se discuten algunos detalles relevantes observados al intercomparar los resultados proporcionados por los diferentes instrumentos.

Palabras clave: Aerosoles, Lidar, Distribuciones de Tamaños.

\section{REFERENCIAS Y ENLACES / REFERENCES AND LINKS}

[1]. P. Forster, V. Ramaswamy, P. Artaxo, T. Berntsen, R. Betts, D. W. Fahey, J. Haywood, J. Lean, D. C. Lowe, G. Myhre, J. Nganga, R. Prinn, G. Raga, M. Schulz, R. Van Dorland., "Changes in atmospheric constituents and in radiative forcing", in Climate Change 2007: The Physical Science Basis, Contribution of Working Group I to the Fourth Assessment Report of IPCC, S. Solomon Edt., pp. 129234, Cambridge Univ. Press, U.K. (2007).

[2]. D. Müller, U. Wandinger, D. Althausen, M. Fiebig "Comprehensive particle characterization from 3wavelength Raman-lidar observations: Case study", Appl. Opt. 40, 4863-4869 (2001).

[3]. M. Sicard, F. Molero, J. L. Guerrero-Rascado, R. Pedros, F. J. Exposito, C. Cordoba-Jabonero, J. M. Bolarin, A. Comeron, F. Rocadenbosch, M. Pujadas, L. Alados-Arboledas, J. A. Martinez-Lozano, J. P. Diaz, M. Gil, A. Requena, F. Navas-Guzman, J. M. Moreno, "Aerosol Lidar Intercomparison in the framework of SPALINET - The Spanish lidar network: Methodology and results", IEEE T. Geosci Remote 47, 3547-3559 (2009).

[4]. J. Bösenberg, V. Matthias, A. Amodeo, V. Amoiridis, A. Ansmann, J. M. Baldasano, I. Balin, D. Balis, C. Böckmann, A. Boselli, G. Carlsson, A. Chaikovsky, G. Chourdakis, A. Comerón, F. De Tomasi, R. Eixmann, V. Freudenthaler, H. Giehl, I. Grigorov, A. Hågård, M. Iarlori, A. Kirsche, G. Kolarov, L. Komguem, S. Kreipl, W. Kumpf, G. Larcheveque, H. Linné, R. Matthey, I. Mattis, A. Mekler, I. Mironova, V. Mitev, L. Mona, D. Müller, S. Music, S. Nickovic, M. Pandolfi, A. Papayannis, G. Pappalardo, J. Pelon, C. Pérez, R. M. Perrone, R. Persson, D. P. Resendes, V. Rizi, F. Rocadenbosch,. A. Rodrigues, L. Sauvage, L. Schneidenbach, R. Schumacher, V. Shcherbakov, V. Simeonov, P. Sobolewski, N. Spinelli, I. Stachlewska, D. Stoyanov, T. Trickl, G. Tsaknakis, G. Vaughan, U. Wandinger, X. Wang, M.Wiegner, M. Zavrtanik, C. Zerefos, "EARLINET: A European Aerosol Research Lidar Network to establish an aerosol climatology”, Rep. 348, Max-Planck Inst. für Meteorol., Hamburg, Germany (2003).

[5]. www.earlinetasos.org

[6]. V. Matthias, V. Freudenthaler, A. Amodeo, I. Balin, D. Balis, J. Bösenberg, A. Chaikovsky, G. Chourdakis, A. Comeron, A. Delaval, F. De Tomasi, R. Eixmann, A. Hågård, L. Komguem, S. Kreipl, R. Matthey, V. Rizi, J. A. Rodrigues, U. Wandinger, X. Wang, "Aerosol lidar intercomparison in the framework of the EARLINET project. 1. Instruments”, Appl. Opt. 43, 961-976 (2004).

[7]. B. Artíñano, P. Salvador, D. G. Alonso, X. Querol, A. Alastuey, "Anthropogenic and natural influence on the PM 10 and PM 2.5 aerosol in Madrid (Spain). Analysis of high concentration episodes", Environ. Pollut. 125, 453-465 (2003).

[8]. P. Salvador, B. Artinano, D. G. Alonso, X. Querol, A. Alastuey, "Identification and characterisation of sources of PM 10 in Madrid (Spain) by statistical methods", Atmos. Environ. 38, 435-447 (2004).

[9]. J. D. Klett, "Stable analytic inversion solution for processing lidar returns", Appl. Opt. 20, 211-220 (1981).

[10]. J. Ackermann, "The extinction-to-backscatter ratio of tropospheric aerosol: A numerical study", J. Atmos. Ocean. Tech. 15, 1043-1050 (1998).

[11]. B. N. Holben, T. F. Eck, I. Slutsker, D. Tanré, J. P. Buis, A. Setzer, E. Vermote, J. A. Reagan, Y. J. Kaufman, T. Nakajima, F. Lavenu, I. Jankowiak, A. Smirnov, "AERONET: A federated instrument network and data archive for aerosol characterization", Remote Sens. Environ. 66, 1-16 (1998).

[12]. T. Nakajima, G. Tonna, R. Rao, P. Boi, Y. J. Kaufman, B. N. Holben, "Use of sky brightness measurements from ground for remote sensing of particulate polydispersions", Appl. Opt. 35, 26722686 (1996). 
[13].F. J. Olmo, A. Quirantes, V. Lara, H. Lyamani, L. Alados-Arboledas, "Aerosol optical properties assessed by an inversion method using the solar principal plane for non-spherical particles", J. Quant. Spectrosc. Ra. 109, 1504-1516 (2008).

\section{Introduction}

The high variability of tropospheric aerosols both in space and time is one of the main reasons of the high uncertainty of radiative forcing estimates in studies of future climate change [1]. The aerosol vertical distribution is of crucial importance in radiative transfer calculations. In studying the vertical structure of the aerosol field and its temporal and spatial evolution, lidar techniques represent a powerful tool because of their capability to provide aerosol profiles with high resolution. Multiwavelength lidars can provide additional information on aerosol characterization because the wavelength dependence of the backscatter and extinction coefficients allows for a more detailed discrimination of aerosol types [2]. Several lidar stations belonging to SPALINET, the Spanish and Portuguese Lidar NETwork [3] and also EARLINET, the European Aerosol Research Lidar NETwork [4] intercompared during a campaign that took place in Madrid from 18 October to 5 November 2010 in the frame of the EARLINET-ASOS project (Advanced Sustainable Observation System) [5]. All network stations routinely perform internal quality checks and participated in intercomparisons both at the instrument and algorithm levels with standardized procedures [6]. In this work, several relevant features shown in the comparison of vertically-resolved optical properties of aerosols with ground-level in situ data and column-integrated aerosol properties provided by sun-photometer remote sensing techniques are discussed. The paper starts with a description of the campaign and the instruments used in section 2. After the presentation of the main results and discussion of several relevant features in section 3 , we present the concluding remarks.

\section{Instrumentation and methodology}

\section{2.a. Site description and intercomparison campaign details}

Experimental data were taken during the SPALI0 (SPAin Lidar Intercomparison 2010) field campaign at Madrid $\left(40.45^{\circ} \mathrm{N}, 3.73^{\circ} \mathrm{W}, 663\right.$ $\mathrm{m}$ asl) from 18 October to 5 November 2010. The Madrid metropolitan area is located in the center of the Iberian Peninsula, bordered to the north-northwest by a high mountain range (Sierra de Guadarrama) $40 \mathrm{~km}$ from the city, and to the northeast and east by lower mountainous terrain. The population of the metropolitan area of Madrid is nearly 6 million inhabitants, with a car fleet of almost 3 million vehicles. Since its industrial activity consists essentially of light factories, the Madrid atmosphere is typically urban, fed by traffic emission and also by domestic heating in winter. Previous studies of air pollution episodes in the Madrid air basin have characterized their driving meteorological conditions and their typical transport patterns [7]. The general synoptic situation leading to the occurrence of episodic events corresponds in winter to stagnant anticyclone conditions, light winds and clear-sky conditions, with the usual formation of radiative nocturnal surface inversions. Long-range transport episodes significantly affecting aerosol concentrations in the Madrid region are usually limited to Saharan mineral dust intrusions [8]. The arrival of Atlantic or polar air masses generally has a cleansing effect on the atmosphere, significantly reducing particulate matter levels. The experimental site at CIEMAT (Centro de Investigaciones Energéticas, Medioambientales $\mathrm{y}$ Tecnológicas) is located in the Madrid North West city outskirts and it can be considered as an urban background or suburban site. It is situated downwind of the city for North to South West wind directions and downwind of a great forested area for West to North West wind directions.

The aim of the SPALI10 campaign was to compare simultaneous lidar measurements from several network stations (Madrid $\left(40.45^{\circ} \mathrm{N}\right.$, $3.73^{\circ} \mathrm{W}, 663 \mathrm{~m}$ asl), Granada $\left(37.16^{\circ} \mathrm{N}, 3.61^{\circ} \mathrm{W}\right.$, $680 \mathrm{~m}$ asl) , Barcelona $\left(41.39^{\circ} \mathrm{N}, 2.11^{\circ} \mathrm{E}, 115 \mathrm{~m}\right.$ asl) and Evora $\left(38.57^{\circ} \mathrm{N}, 7.91^{\circ} \mathrm{W}, 293 \mathrm{~m}\right.$ asl)) 
with a reference lidar system from CNR-IMAA (Potenza, Italy. $40.60^{\circ} \mathrm{N}, 15.72^{\circ} \mathrm{E}, 760 \mathrm{~m}$ asl) in order to assess their performances measuring the same atmosphere during the same time periods. At the same time, an extensive dataset from both ground-level in-situ measurements and remote sensing techniques was collected for characterizing aerosol optical and microphysical properties. All lidar systems were collocated close on a flat terrain, with laser pointing close to the zenith. Several sessions each with some hours of measurement time were scheduled for every day of the campaigns, both at day and night, in order to obtain long enough periods with stable atmospheric conditions and with all lidar systems working properly. The first week of the campaign was addressed to the instrument setup and to the verification that the data were correctly submitted to be automatically pre-processed by means of the Single Calculus Chain. During the following two weeks, measurement sessions were regularly scheduled during nighttime and daytime sessions on the base of the weather forecasts. Measurement sessions lasted at least three hours to allow for long enough time intervals to evaluate the stability of particular vertical atmospheric structures (e.g. clouds, aerosol layers), in order to select the best time intervals for signal averaging. During a daily meeting, the measurements were discussed and decisions about the corrections on the systems were individuated. The results of the campaign can be considered satisfactory as the campaign allowed to check the performances of the systems and when they were not fully satisfactory, the reasons of the failure were understood and the way to solve them were defined.

\section{2.b. Instruments}

All the intercompared lidar systems use pulsed $\mathrm{Nd}$ :YAG laser emitting at 1064, 532 and $355 \mathrm{~nm}$, configured in a monostatic biaxial alignment pointing vertically to the zenith, except for the Evora system, that is tilted 5o to improve cirrus studies. The receiving lines consist of Cassegrain or Newtonian telescopes and wavelength separation units with dichroic mirrors, interferential filters and polarization cubes. Potenza and Granada systems are 3+2 lidar systems equipped with channels for cross and parallel polarized radiation at $532 \mathrm{~nm}$; Madrid and Barcelona are 3+2 lidar systems, whereas the Evora system does not measure at $1064 \mathrm{~nm}$. From the elastic lidar signal, aerosol backscatter coefficient profiles have been retrieved using the Klett algorithm [9]. Temperature and pressure profiles provided by radiosondes data were used to calculate molecular backscatter profiles. Lidar signals can be fitted to this calculated "Rayleigh" profiles to choose the aerosol-free vertical range for the reference value required by the inversion algorithm. The retrieval of backscatter coefficient profiles requires the use of a modelled value for the lidar ratio (i.e., the ratio between aerosol extinction and backscatter coefficient). Considering the work of Ackermann [10], that established that aerosol extinction-tobackscatter ratio increases with the relative humidity from 40 to $80 \mathrm{sr}$ for continental aerosol, a value of $50 \mathrm{sr}$ was chosen based on the relative humidity measured at ground-level.

The column integrated characterization of the atmospheric aerosol was performed by means of an automatic sun tracking photometer Cimel CE-318-4 [11], operated by the Granada team. This instrument makes direct sun irradiance measurements with a $1.2^{\circ}$ full field of view every $15 \mathrm{~min}$ at $340,380,440,670,870$, 940 and $1020 \mathrm{~nm}$. These solar extinction measurements are then used to compute Aerosol Optical Depth (AOD) at each wavelength except for the $940 \mathrm{~nm}$ channel, which is used to retrieve total column water vapor. The AOD is derived from the total optical depth obtained from direct sun-photometer measurements data. The sky radiance measurements, performed at the almucantar and principal planes at 440, 675, 870 , and $1020 \mathrm{~nm}$ together with solar direct irradiance measurements at the same wavelengths, were used to retrieve the aerosol single-scattering albedo, phase function, aerosol optical depth and the volume size distribution $\left(d V(r) / d \mathrm{ln} r \quad\left(\mathrm{~cm}^{3} \mathrm{~cm}^{-2}\right)\right)$ using the radiative transfer code SKYRAD.pack software [12]. This software package consists of a radiative transfer code as well as linear and nonlinear inversion components based on spherical particle assumption. However, for the accurate retrieval of aerosol properties from sky radiation measurements, the influence of nonsphericity 
Table I

List of instruments used in this study.

\begin{tabular}{|c|c|c|c|}
\hline Meas. Type & Instrument & Model & Quantities used in this study \\
\hline \multirow{3}{*}{ In-situ } & Scanning mobility particle sizer & TSI SMPS 3936 & Number size dis. 0.008-0.3 $\mu \mathrm{m}$ \\
\cline { 2 - 4 } & Optical particle counter & GRIMM 1108 & Number size dist. 0.15-10 $\mu \mathrm{m}$ \\
\cline { 2 - 4 } & Optical particle counter & GRIMM 1107 & PM10, PM2.5 and PM1.0 \\
\hline \multirow{2}{*}{ Column } & Sun-photometer & CIMEL CE318-4 & $\begin{array}{c}\text { Aerosol optical depth } \\
\text { Volume size dist. 0.01-10 } \mu \mathrm{m}\end{array}$ \\
\hline \multirow{2}{*}{ Range-resolved } & Lidar & Lab. instruments & \begin{tabular}{c} 
Aerosol backscatter coefficient \\
\cline { 2 - 4 }
\end{tabular} \\
\cline { 2 - 4 } & Radiosoundings & Vaisala RS 92 & $\begin{array}{c}\text { Temperature, dew point } \\
\text { temperature, pressure }\end{array}$ \\
\hline
\end{tabular}

was also included for improving retrievals for large dust particles [13].

At ground level, the temporal evolution of particle number concentration for particles with aerodynamic diameter smaller than 10, 2.5 and 1 $\mu \mathrm{m}$ (PM10, PM2.5 and PM1, respectively) were monitored at the experimental site. Dry ambient sub-micrometer size distributions were monitored at the site by using a Scanning Mobility Particle Sizer (TSI SMPS 3936), combining a long Differential Mobility Analyzer (DMA) and a Condensation Particle Counter (CPC model 3775) working in the scanning mode. On a larger particle size range, an Optical Particle Counter (GRIMM 1108) was used. Both instruments allow to obtain a single plot for number distributions between 0.015 to $10 \mu \mathrm{m}$ by joining their data. Volume distributions $(d V / d \log (D p))$ were calculated assuming that aerosol particles were spheres with a radius equal to the centre radius of each bin measured by the instruments. Instruments details and information provided are summarized in Table I.

\section{Results and discussion}

\section{3.a. Synoptic situation}

The meteorological analysis shows a synoptic situation mainly governed by high-pressure systems over the Iberian Peninsula during the first two weeks of the campaign, promoting stagnation. After these days there was a three days rain episode ending on $31^{\text {st }}$ October, followed by a period with the Azores highpressure system dominating over the peninsula, yielding the entry of air masses from the Atlantic.

\section{3.b. Aerosol temporal evolution}

The temporal evolution of PM10, PM2.5 and PM1 mass concentration at the surface are shown in the bottom panel of Fig. 1. The local pollution events produced by traffic rush hours, normally between 7:00 and 9:00 local time, but sometimes extending until midday, are clearly identified by sharp peaks of PM10. PM2.5 and PM1 show a similar trend, but less pronounced. Between these pollution peaks, the background pollution levels increased from day-to-day between 26 and 29 October due to stagnation of the air mass. As a result, there was an increase of aerosol concentration near the surface, with the PM10 reaching the daily average limit established by the European Union (> $50 \mu \mathrm{g} \mathrm{m}^{-3}$ ). On the other hand, the synoptic situation between 31 October and 5 November allowed the cleaning of the atmosphere from day-to-day, with lower PM10, PM2.5 and PM1 mass concentration, especially for PM10, with nearly half values compared to those before the rain episode that took place between the 29 and 31 October. The results are consequence of the changes in synoptic situation, where the presence of a stagnation increase particle concentration levels and the inflow of Atlantic air masses avoid the accumulation of pollution from previous days, thus reducing particle concentration near the surface.

\section{3.c. Lidar profiles comparison}

The comparison of lidar systems was performed among the range-corrected signals (RCS, raw signals multiplied by the square power of the range) after pre-processing. Fig. 2 shows the comparison of the RCS averaged nearly one hour at their elastic wavelengths for 3 November 
nighttime session. Signals have been truncated at the full-overlap height, that changes from system to system. All systems correctly resembles the reference profile with deviations smaller than $20 \%$ for 355 and $532 \mathrm{~nm}$ and smaller than $30 \%$ for $1064 \mathrm{~nm}$, fulfilling the EARLINET criteria [6]. Madrid did not measure at $355 \mathrm{~nm}$ and Evora at $1064 \mathrm{~nm}$. The large noise of Granada $1064 \mathrm{~nm}$ signal was due to a partial masking of the telescope in order to correct a problem related to the position of the pinhole. This problem was not correctly identified and corrected until the last week of the campaign, when the other systems were testing different detectors and set up than precluded some of the channels to be used. For this reason, there was not possible to show a session with all the channels for all the systems measuring simultaneously and showing good agreement.

Figure 3 left panels shows aerosol backscatter profiles, derived from the Madrid system range-corrected signals, at the three elastic wavelengths, for 21 October and 2 November daytime sessions, along with the vertical water vapor mixing ratio provided by the radiosounding. There was a thermal inversion at $990 \mathrm{~m}$ asl, determined by the inflexion point of the virtual potential temperature profile (not shown). This reduced height, together with the synoptic situation at that time and the low wind speed near the surface, were responsible for the increased concentration of particles at ground level (see Fig. 1). The extinction coefficient profile shows another layer, between 1050 and $1250 \mathrm{~m}$ asl, with smaller mixing layer values than the PBL, but similar extinction coefficient values. Another layer, with very low extinction coefficient values and dry conditions was observed between 2700 and $3800 \mathrm{~m}$ asl. Next to the right of the aerosol backscatter profiles plots of the Fig. 3, the color ratios obtained between the 532 and $355 \mathrm{~nm}$ (black line) and 1064 and $532 \mathrm{~nm}$ (red line) profiles have been plotted. They show values around 1 for the mixing layer aerosols, but the $532 / 355 \mathrm{~nm}$ ratio decreases to nearly 0.5 for the aloft layer, indicating a different type of aerosol.
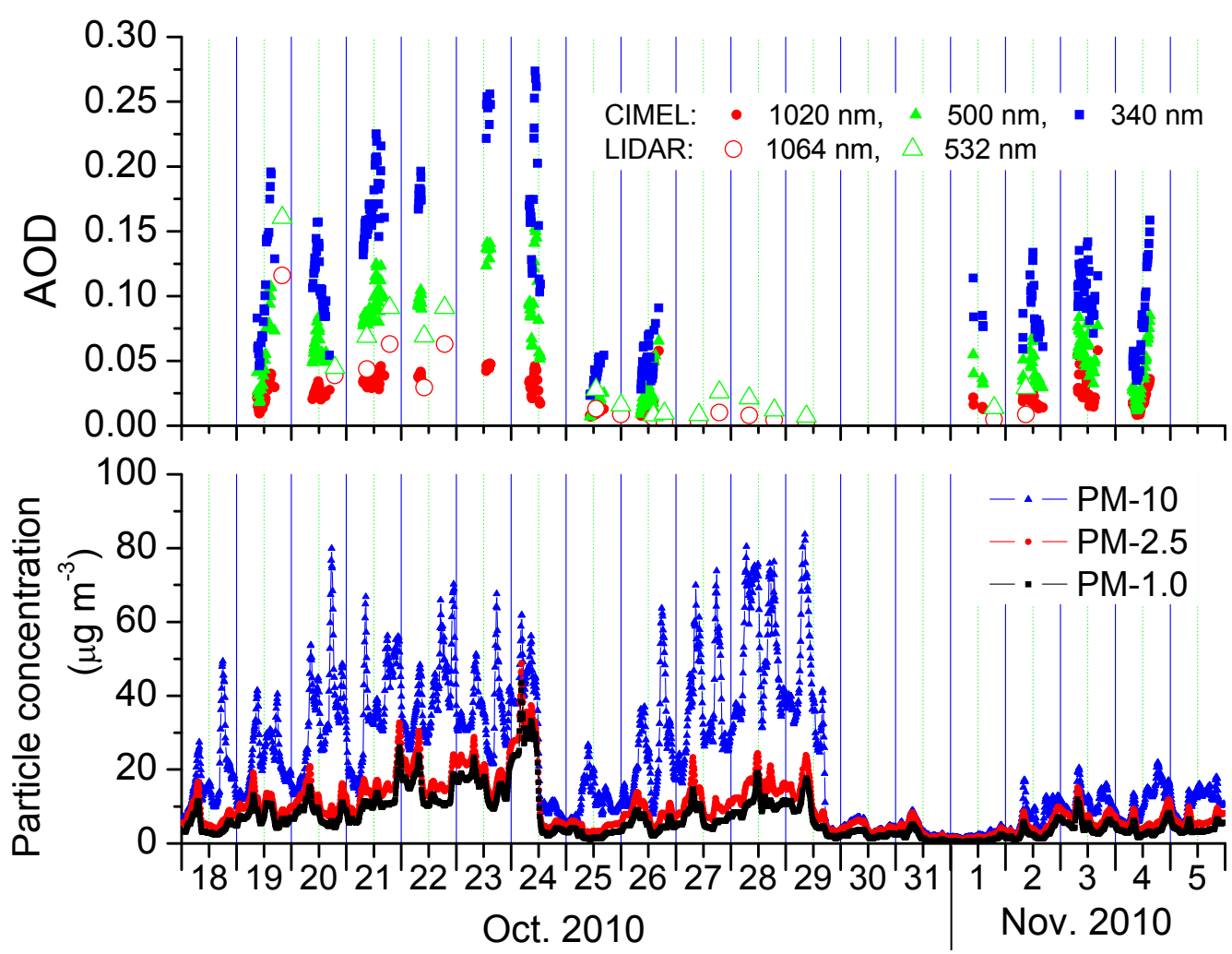

Fig. 1: Temporal evolution of PM1, PM2.5 and PM10 aerosol concentration (bottom panel), and AOD provided by Lidar (open symbols) and CIMEL (solid symbols) at wavelengths closest to lidar's (top panel) from 18 Oct to 5 Nov at the Madrid site. 

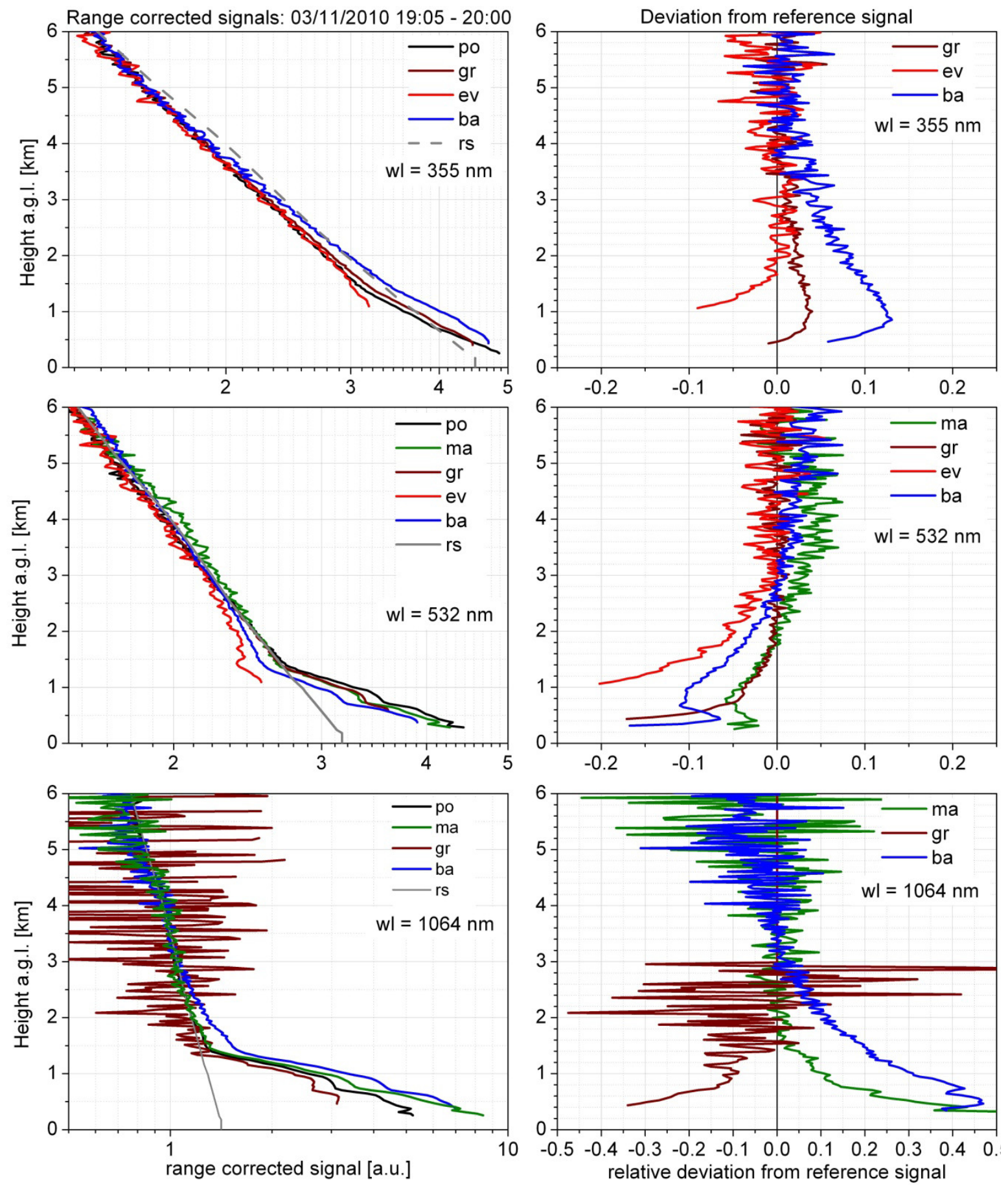

Fig. 2: Range corrected signals, on left panels, for the systems intercompared: Potenza (po, Black), Madrid (ma, Green) Granada (gr, Wine), Evora (ev, Red) and Barcelona (ba, Blue) and deviations from the reference system on the right panels. 

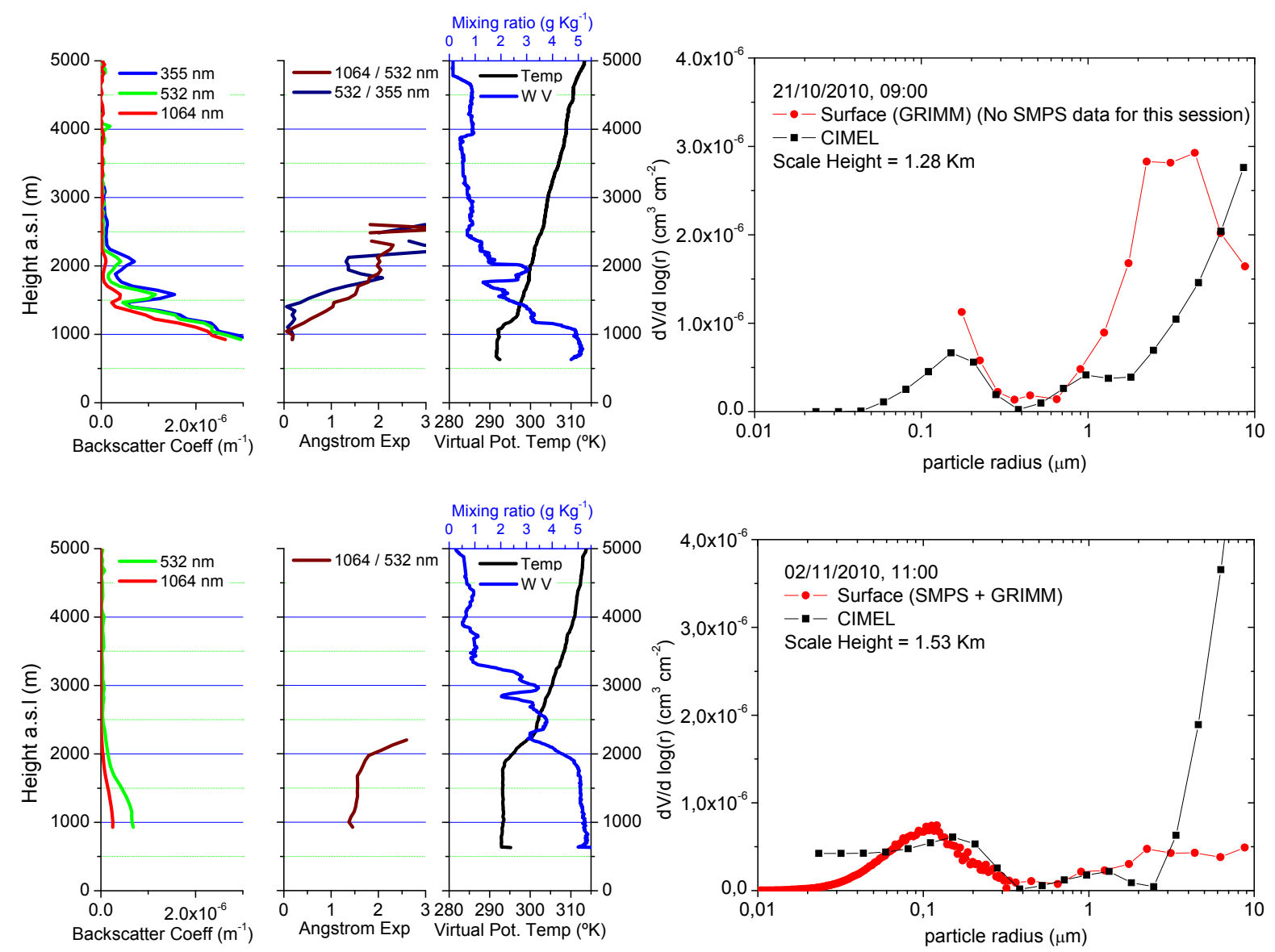

Fig. 3: Left panels: Vertically-resolved aerosol properties (extinction coefficient, Angström exponent) and radiosounding parameters (virtual potential temperature and water vapor mixing ratio), Right panels: Semilog plot of the columnar volume size distribution calculated from CIMEL data (black squares) and converted from ground-level measurements (red circles) by means of the scale height $(\mathrm{H})$ provided by lidar system $(N(h)=N(0) \exp [-x / H])$ at Madrid. Top panels correspond to the 21 Oct, $9 \mathrm{~h}$ session and bottom panels to the 2 Nov, $11 \mathrm{~h}$ session.

Finally, the column-integrated volume size distributions provided by the sun-photometer was compared with the one obtained at groundlevel, using the lidar profiles to determine the scale height required to make them comparable. The two techniques measure different quantities; sun-photometer remote sensing is sensitive to the aerosol optical properties of the entire column, while in-situ instruments measure the aerosols at ground-level, which may not be representative of the distributed aerosol in the total boundary layer. The distributions obtained by in-situ instrumentation at surface level (in $\mu \mathrm{m}^{3} \mathrm{~cm}^{-3}$ ) are converted into columnar distribution $\left(\mu \mathrm{m}^{3} \mathrm{~cm}^{-2}\right)$ for comparison with sun-photometer retrievals by means of a scale height that corresponds to the altitude where the integrated extinction is equal to $1-\mathrm{e}^{-1}$ of the retrieved AOD for a given lidar profile.
Top right panel of Fig. 3 shows aerosol volume size distribution vs. radius between 0.01 and $10 \mu \mathrm{m}$, in logarithmic scale, obtained on $21^{\text {st }}$ October at 9:00 UTC. The observed size distributions are typically bimodal, with the first modal radius between $<0.015$ and $0.4 \mu \mathrm{m}$, and the second between 0.5 and $>10 \mu \mathrm{m}$. Between these modal values generally there is a minimum (inflection point), corresponding to a radius of about $0.4 \mu \mathrm{m}$. The agreement between the volume size distribution provided by the inversion code and that measured at groundlevel was reasonable, taking into account the assumptions made for the comparison. The presence of aloft layer with a different type of aerosol, although with very low extinction values, might influence the comparison, raising concern about the validity of the scale height value employed in the conversion of the surface 
data. Bottom right panel of Fig. 3, obtained on 2 November at 11:00 UTC, when the mixing layer was homogeneous up to $2 \mathrm{~km}$, shows smaller discrepancy, thus supporting this explanation.

\section{Conclusions}

During the SPALI10 lidar intercomparison campaign at Madrid, the products provided by multiwavelength lidar systems were compared with ancillary instrumentation data. Along the campaign, each lidar system worked to solve the discrepancies observed when compared with the reference system and it can be concluded that all channels from all systems fulfilled the required EARLINET criteria, with deviations smaller than $20 \%$ for 355 and $532 \mathrm{~nm}$ and smaller than $30 \%$ for $1064 \mathrm{~nm}$. At ground level, aerosol size distributions were continuously monitored between $15 \mathrm{~nm}$ and $10 \mu \mathrm{m}$ by merging two particle counters. Additionally, the columnintegrated characterization of the atmospheric aerosol was performed by means of a sunphotometer. The vertically-resolved aerosol optical properties at three wavelengths provide information about the type of aerosol present in the different layers observed. A comparison of columnar versus ground-level measurements of aerosol size distribution was performed. Two different synoptic situation were analyzed, firstly, a stagnation scenario (21 $1^{\text {st }}$ October), with pollution concentrations growing for one day to the next; secondly, a clean atmosphere scenario ( $2^{\text {nd }}$ November), dominated by the arrival of
Atlantic air masses, with low atmospheric pollution. In-situ measurements at ground-level were converted into column-integrated values using the retrieved scale height values provided by lidar profiles. Both techniques yield bimodal aerosol size distribution in both scenarios, with an inflection point around $0.4 \mu \mathrm{m}$. Columnintegrated size distributions provided by the sun tracking photometer match this bimodal shape, especially in the size range between 0.2 and 2 $\mu \mathrm{m}$, where the inversion algorithm is more reliable. On the other hand, absolute values disagree and the shape of each mode (fine and coarse) did not resemble the ground-level data. Aerosol layer structure detected by the lidar system might explain the discrepancy observed in the absolute values and shape of each mode. Further investigations are ongoing to obtain relevant vertically-resolved aerosol optical properties from multiwavelength Raman lidar systems.

\section{Acknowledgements}

This work was supported by the European Union under project no 025991 (RICA), by the Spanish Ministry of Science and Technology through project CGL2010-17777 (PHAESIAN), CGL2008-01330-E/CLI (Spanish Lidar Network) and CGL2010-09225-E (Campaña internacional de intercomparacion de sistemas lidar en Madrid) and by the ESA-CEOS Intercalibration of Ground-Based Spectrometers and Lidars (CEOSIC-PR01) project. 